\title{
Assessing the Microbial Quality (Listeria monocytogenes) of Chicken Meat by Polymerase Chain Reaction in Different Areas of Chennai
}

\author{
S. Satheesh Raja*, V. Apparao, R. Narendra Babu and M. Thamizhannal
}

Department of Meat Science and Technology, Madras Veterinary College, Chennai, India

*Corresponding author

A B S T R A C T

\begin{tabular}{|c|c|}
\hline & dely distributed and found $i$ \\
\hline $\begin{array}{l}\text { L.mono } \\
\text { Polym } \\
\text { Reactio }\end{array}$ & $\begin{array}{l}\text { Post processing contamination is the major source and cross contamination may also } \\
\text { occur at the retail shop and also in products due to improper hygienic practices. A }\end{array}$ \\
\hline Article Info & $\begin{array}{l}\text { study was conducted to identify the presence of } L \text {. monocytogenes in chicken meat by } \\
\text { polymerase chain reaction. } 40 \text { samples were collected from different areas of Chennai }\end{array}$ \\
\hline $\begin{array}{l}\text { Accepted: } \\
10 \text { April } 2018 \\
\text { Available Online: } \\
10 \text { May } 2018\end{array}$ & $\begin{array}{l}\text { and were tested for the presence of } L \text {. monocytogenes by targeting prfA gene with } \\
290 \text { bp by PCR. None of the samples were shown to be positive for L. monocytogenes. } \\
\text { The test reveals that the processing can be performed hygienically. }\end{array}$ \\
\hline
\end{tabular}

\section{Introduction}

Meat can be contaminated at various stages of production by most of the microorganisms. Microbial quality of meat is an important aspect for industries engaged in production, processing and distribution. It is very persistent microorganism that survives on surfaces and equipment of food processing units in conditions of insufficient cleaning. Post processing contamination is the major source and cross contamination may also occur at the retail shop and also in products due to improper hygienic practices. Ingestion of uncooked meat contaminated during processing can produce infection. $L$. monocytogenes was found prevalently high in poultry meat $(24.5 \%)$, intermediate in beef meat $(24.4 \%)$ and less prevalent in pork meat (21.4\%). Listeria monocytogenes has also been found in raw or processed foods like meat and seafood (Gugnani, 1999; Meng and Doyle, 1997). Listeriosis is a food borne infection with flu-like symptoms in healthy people and severe complications in immunecompromised children, pregnant women and elderly person (Pesavento et al., 2009). Hence a study is planned to conduct a screening of chicken meat for the presence of L. monocytogenes in different zones of Chennai with PCR.

\section{Materials and Methods}

Chicken meat samples of around 40 numbers were collected from different retail outlets of Chennai city. The samples placed in sterile 
polythene bags and transported hygienically to the Department of Meat Science and Technology, Madras Veterinary College, Chennai -7 in clean insulated box with ice packs. Before screening, 25 gram of meat sample was homogenized in $225 \mathrm{ml}$ of BPW and incubated at $37^{\circ} \mathrm{C}$ for 18 hours.

The meat homogenate obtained was then subjected to DNA extraction using Bacterial DNA extraction kit and PCR analysis for the presence of $L$. monocytogenes by targeting prfA gene with $290 \mathrm{bp}$. A $20 \mu \mathrm{l}$ of reaction mixture was set up in $0.2 \mathrm{ml}$ PCR tube with following components such as master mix $10 \mu \mathrm{l}$, forward primer-1 $\mu \mathrm{l}$, reverse primer-1 $\mu \mathrm{l}$, template DNA-1 $\mu \mathrm{l}$ and nuclease free water-7 $\mu$ l. The PCR amplification was carried out in Master Cycler Gradient Thermo cycler (M/s. Eppendorf, Germany) with the following cycling conditions of initial denaturation at $94^{\circ} \mathrm{C}$ for 5 minutes, followed by 30 cycles of denaturation $\left(94^{\circ} \mathrm{C}\right.$ for 30 seconds), annealing $\left(52^{\circ} \mathrm{C}\right.$ for 30 seconds) and extension $\left(72^{\circ} \mathrm{C}\right.$ for 30 seconds $)$ and subsequently a final extension at $72^{\circ} \mathrm{C}$ for 7 minutes. The PCR product obtained was subjected to electrophoresis in 2\% Agarose gel. Ethidium bromide with concentration of $10 \mathrm{mg} / \mathrm{ml}$ was added at the rate of $5 \mu 1 / 100 \mathrm{ml}$ of Agarose. Electrophoresis is carried out using 1X TAE buffer at 100 volts for 30 minutes. The gel was viewed under UV illuminator and documented using gel documentation system.

\section{Results and Discussion}

Around 40 chicken meat samples were collected from different retail outlets of Chennai. The meat homogenate obtained was subjected to DNA extraction using Bacterial DNA extraction kit and the developed PCR was used to detect Listeria monocytogenes. None of the sample showed positive for the presence of Listeria monocytogenes in the retail chicken meat by PCR (Figure 1 and 2). Screening of chicken meat from different zone wise details were given below (Table 1).

Fig.1

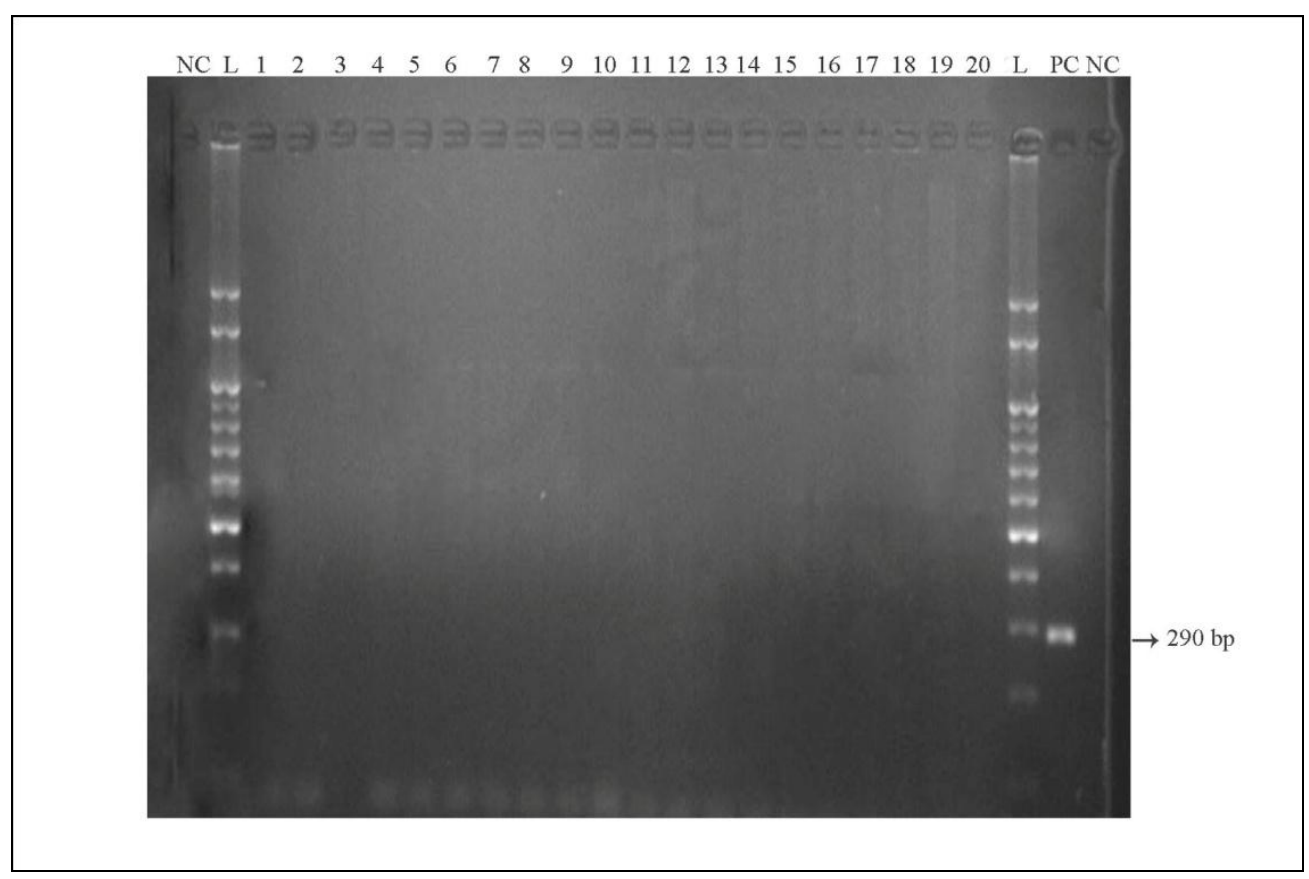


Fig.2

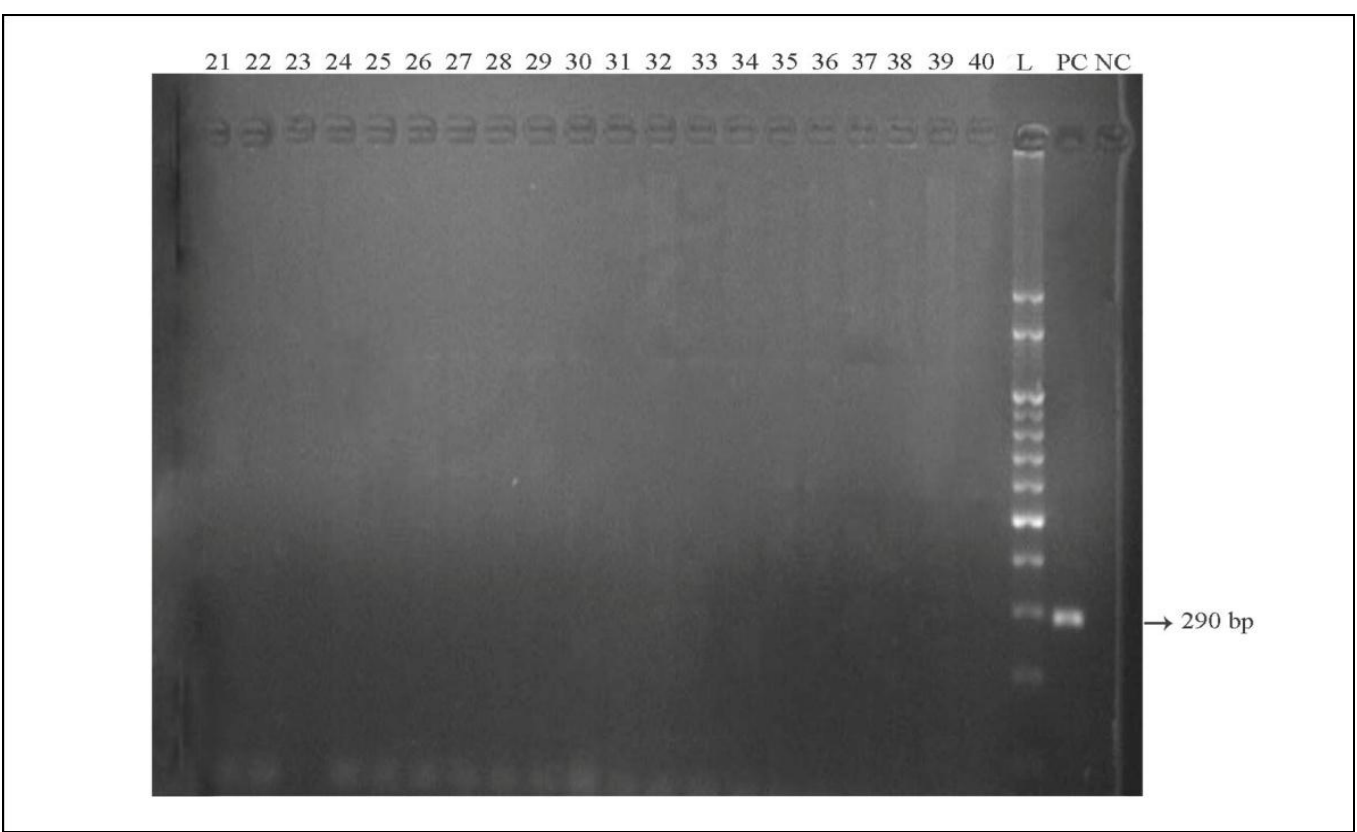

Note: L: 100 bp DNA Ladder, 1-20, 20-40: Sample result showing absence of L. monocytogenes in chicken meat, PC: Positive control of L. monocytogenes with 290bp, NC: Negative control

Table.1 Screening of chicken meat samples collected from different retail outlets of Chennai

\begin{tabular}{|c|c|c|c|}
\hline Zone & Name & No. of & No. of positive samples by m-PCR \\
\hline & samples & Listeria monocytogenes \\
\hline $\mathbf{1}$ & Manali & 6 & - \\
\hline 2 & Tondiarpet & 6 & - \\
\hline 3 & Thiru-vi-ka nagar & 6 & - \\
\hline 4 & Valasaravakkam & 6 & - \\
\hline 5 & Alandur & 6 & - \\
\hline 6 & Perungudi & 5 & - \\
\hline 7 & Adyar & 5 & - \\
\hline & Total & 40 & 0 \\
\hline
\end{tabular}

This study states that screening of chicken meat samples from retail outlets were carried out to assess the usefulness of the PCR technique and the level of processing of retail chicken meat. The 40 chicken meat samples collected from different areas of Chennai city were not positive for Listeria monocytogens. The existence and control of Listeria species and Listeria monocytogenes in broiler's ceca, meat and skin at the retail outlets of Ismailia city were studied in Egypt. The results of the study revealed that 92, 42 and 70 percent of broiler's ceca, meat and skin respectively were contaminated with Listeria spp. From the Listeria spp. positive samples, L. monocytogenes were highest in ceca (60\%, 30 of 50 samples), followed by skin (34\%, 17 of 50 samples), and meat (16\%, 8 of 50 samples) (Ahmed and Nashwa, 2010). Screening of food samples like ground meat, beef and pork revealed the presence of 10 copies / $\mu \mathrm{l}$ of Listeria monocytogenes (Zhang et al., 2009). He detected $10^{5} \mathrm{CFU} / \mathrm{ml}$ of Listeria monocytogenes in $500 \mu \mathrm{l}$ of pre-enrichment broth without incubation and $3 \times 10^{1} \mathrm{CFU} / \mathrm{ml}$ 
after incubation (Barocci et al., 2008). Listeria monocytogenes was detected in pork sausage and mozzarella cheese at a contamination level of $1 \mathrm{CFU} / \mathrm{g}$ before culture enrichment (Amagliani et al., 2007). This study reveals that PCR is one of the effective and time saving methods to detect microorganism. Hence the process is carried out in a hygienic manner or there may be some other reason for the absence of microorganism in chicken meat. Similarly $\mathrm{He}$ (Kozacinski et al., 2006) conducted a study to assess the microbial quality of chicken meat in Croatian market and reported L.monocytogenes in chicken breast and skin (4.76\%). A study was conducted to detect the prevalence of Listeria spp. in raw chicken and ready-to-eat (RTE) chicken products in Amman, Jordan and they found that L. monocytogenes was present in 9.4\% of fresh dressed broiler chickens, $13.3 \%$ of RTE chicken-shawirma, $76.7 \%$ of RTE chickenburger, and $30 \%$ of RTE chickensausages whereas mortadella samples were free of L. monocytogenes. (Osaili et al., 2011).

\section{Acknowledgments}

I am very much grateful to all my Department staffs and my friends who have helped me in collecting samples from different areas of Chennai.

\section{References}

Ahmed, M.A. and Nashwa, M.A. 2010. Existence of Listeria species in broiler carcasses with an attempt to control Listeria monocytogenes using trisodium phosphate. African Journal of Food Science, 4: 46-51.

Amagliani, G., Giammarini, C., Omiccioli, E., Brandi, G., Magnani, M. 2007. Detection of Listeria monocytogenes using a commercial PCR kit and different DNA extraction methods. Food Control, 18: 1137-1142.

Barocci, S., Calza, L., Blasi, G., Briscolini, S., Curtis, D.M., Palombo, B., Cucco, L., Postacchini, M., Sabbatini, M., Graziosi, T., Nardi, S. and Pezzotti, G. 2008. Evaluation of a rapid molecular method for detection of Listeria monocytogenes directly from enrichment broth media. Food Control, 19: 750-756.

Gugnani, H.C. 1999. Some emerging food and water borne pathogens. Journal of Communicable Disease, 31: 65-72.

Kozacinski, L., Hadziosmanovic, M. and Zdolec, N. 2006. Microbiological quality of poultry meat on the Croatian market. Veterinarski arhiv, 76: 305-313.

Meng, J. and Doyle, M.P. 1997. Emerging issues in microbiological food safety. Annual Review of Nutrition, 17: 255275.

Osaili M. T., Alaboudi A.R. and Nesiar E.A. 2011, "Prevalence of Listeria spp. and antibiotic susceptibility of Listeria monocytogenes isolated from raw chicken and ready-to-eat chicken products in Jordan." Food Control, 22: 586-590.

Pesavento, G., Ducci, B., Nieri, D., Comodo, N. and Nostro, A.L. 2010. Prevalence and antibiotic susceptibility of Listeria spp. isolated from raw meat and retail foods. Food Control, 21: 708-713.

Zhang D., Zhang, H., Yang, L., Guo, J., X. L and Feng, Y. 2009. Simultaneous detection of Listeria monocytogenes, Staphylococcus aureus, Salmonella enterica and Escherichia coli O157: H7 in food samples using multiplex PCR method. Journal of Food Safety, 29: 348363.

\section{How to cite this article:}

Satheesh Raja, S., V. Apparao, R. Narendra Babu and Thamizhannal, M. 2018. Assessing the Microbial Quality (Listeria monocytogenes) of Chicken Meat by Polymerase Chain Reaction in Different Areas of Chennai. Int.J.Curr.Microbiol.App.Sci. 7(05): 932-935. doi: https://doi.org/10.20546/ijcmas.2018.705.114 